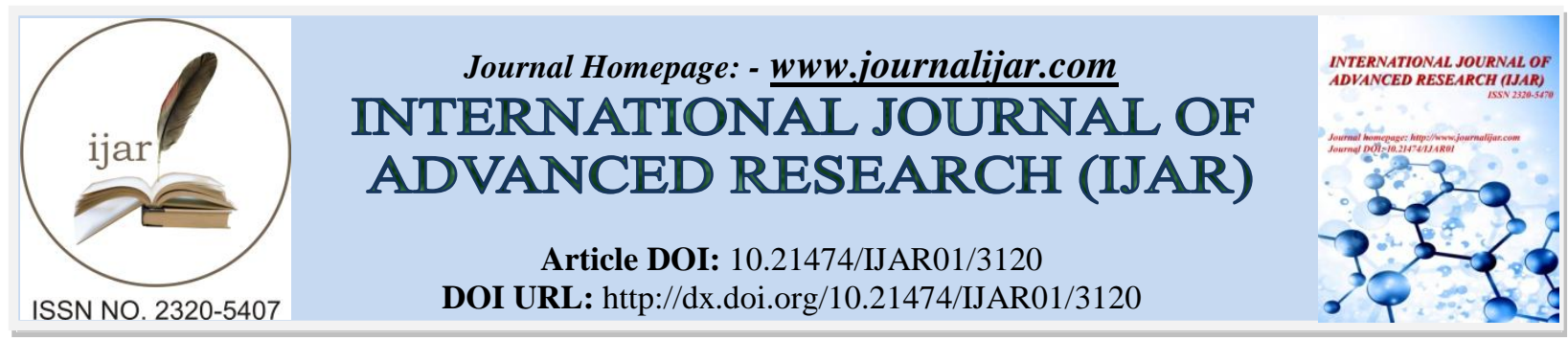

RESEARCH ARTICLE

\title{
INCREASING THE COMPETENCE OF UNIVERSITY STUDENTS' LEARNING RESULTS IN THE ENGINE ELEMENTS COURSE BY BENEFITTING THE MACHINERY TOOLS IN THE ENGINEERING LABORATORY OF SEMARANG STATE UNIVERSITY ${ }^{10}$.
}

Murdani.

Lecturers of Mechanical Engineering Department, Faculty of Engineering, Semarang State University_Indonesia.

\section{Manuscript Info}

Manuscript History

Received: 08 December 2016

Final Accepted: 12 January 2017

Published: February 2017

Key words:-

laboratorium-based engineeering learning.

\begin{abstract}
The study was to find the improvement on the competence of university students' learning results in the Engine Elements Course in the topic of Shaft Planning and Calculation. The competencies that would be improved were knowledge, analysis, calculation results and cummulative learning results. In order to achieve the objective of the study, the researcher implemented a quasi-experiment method by selecting 49 university students to be given lesson and be tested. There are three types of learning stages. The first stage consisted of theoretical study and test. Then, the second stage consisted of laboratory study and test. Last but not the least, the third stage consisted of laboratory observation and test. The analysis that the researcher performed in the stud was the Partial Least Square (PLS) analysis in order to identify the differences from one test to another.From the results of the study, there were three aspects which results improvement might be measured, namely knowledge (A), analysis (B) and calculation results (C). The learning results improvement between knowledge $\mathrm{A} 1$ and knowledge $\mathrm{A} 2$ was $3.5 \%$ and between knowledge A2 and knowledge A3 was $1.1 \%$. Then, the learning results improvement between analysis $\mathrm{B} 1$ and analysis $\mathrm{B} 2$ was $40.0 \%$ and between analysis B2 and analysis B 3 was $10.5 \%$. Next, the learning results improvement between calculation results $\mathrm{C} 1$ and calculation results $\mathrm{C} 2$ was $59.4 \%$ and between calculation results $\mathrm{C} 2$ and calculation results $\mathrm{C} 3$ was $46.1 \%$. Altogether, the improvement on the learning results competency between $\mathrm{P} 1$ and $\mathrm{P} 2$ was $25.6 \%$ and between $\mathrm{P} 2$ and $\mathrm{P} 3$ was $14.89 \%$.
\end{abstract}

Copy Right, IJAR, 2017,. All rights reserved.

\section{Introduction:-}

Learning is a process that cultivates a set of values that have been consumed by the students and that have been taken from multiple sources. According to Arief Sadiman $(2002)^{1}$, learning sources might be classified into five categories namely: human, books/library, mass media, natural environment and educational media. In other words, learning sources refer to every single matter that might be used as a place where the teaching materials might be attained or where the origin of an individual's learning process might be attained. The engineering laboratory might also serve as an educational media that assists the teachers in enriching the learning participants' insight. In

Corresponding Author:- Murdani.

Address:- Lecturers ofMechanical Engineering Department, Faculty of Engineering, Semarang State 
explaining an object, a lecturer might take his or her students to a laboratory. By the looking at the objects in the laboratory, these objects might serve as learning sources.

Learning medium as an assisting tool serve to ease the way in achieving the teaching objectives. The statement is based on a belief that the teaching-learning process with the assistance of the media may improve the learning participants' learning activities within a long period of time. In other words, the learning participants' learning activities that are assisted by the learning medium will result in better learning process and results. Ali Imron $(2002)^{2}$ provides limitation regarding media, namely medium refers to any form and material that has been used for delivering message or information. In addition to serving as a system of delivery or introduction, media that has been derived from the word mediator, according to Azhar (2002) ${ }^{3}$, is a cause or a tool that interferes two parties in order to provide peace among the two parties. With the term mediator, the media shows its role or function namely to regulate an effective relationship between two main parties in the students' learning process and the learning content. If the media deliver instructional messages or information, or if the media contain the teaching intentions, then the media will be regarded as teaching media.

According to Azhar $(2003)^{3}$, there are three main levels in the learning mode namely direct experience (enactive level), pictorial experience (iconic level) and abstract experience (symbolic level). Such experience level in attaining the learning results is depicted as a process of communication. The materials that the teachers want to deliver and that the students demand, until the students master all of the materials, are known as messages. The teachers as the source put the messages into certain symbols (encoding process) and the students as the retriever will interpret these symbols in order to understand these symbols as messages (decoding process). Learning by using double senses (the vision and the auditory) will gain more results compared to learning by only using the vision or the auditory. The comparison on the learning results between the vision and the auditory has significant difference. Approximately $90 \%$ of an individual's learning results are attained by the vision and only $5 \%$ of those are attained by the other senses $^{12}$. On the other hand, Arief Sardiman $(2002)^{1}$ predicts that the students attain $75 \%$ of their learning results from the vision, $13 \%$ of their learning results from auditory and $12 \%$ of their learning results from other senses.

In a learning process, two most important elements are the teaching methods and the learning media. The selection of certain teaching methods will influence the type of appropriate learning media. Several aspects that should be given attention in selecting the media are: the learning objectives, the learning contexts, the lesson types and the students' characteristics. All of these aspects are expected to be mastered by the students after the learning process has occured. Skinner $(1998)^{4}$ state that there are four functions of learning media, especially the visual learning media, namely the attentive function, the affective function, the cognitive function and the compensatory function. The four functions might support one to another so that they will strengthen one to another in the learning process. Then, according to Jujun $(2003)^{5}$, learning media might meet the three main functions namely to motivate interest or action, to provide information and to give instruction. Learning media might also be implemented for individual, group or hugh group of listeners. Saiful Sagala $(2001)^{6}$ states the benefits of using learning media in the students' learning process as follows: the learning media will draw more attention, the learning materials will have clearer meaning, the teaching methods will be more various and the students might display more learning desire. From the opinions of several experts, the researcher might conclude several practical benefits from the use of learning media, namely to ease and to increase the learning process and results. From the perspective of learning theory, multiple conditions and psychological principles that should be considered in selecting and in using the learning media are related to the improving the students' motivation.

An effective teaching is the result of good learning plan; therefore, the learning media that will be used in the teaching process should also have good planning. Several aspects that should be considered by the teachers in selecting the learning media for the class activities are: the selected media are easy to use, the selected media might provide better explanation, the selected media might draw the students' interest and attention and the selected media might lead to the more structured and organized presentation. The consideration is expected to meet the needs in achieving the objectives that have been formulated.

Competence, on the other hand, refers to the capacity of performing certain jobs that include the aspects of knowledge, skills and attitudes. Therefore, competence might be improved. According to Spencer \& Spencer $(1990)^{7}$, Essential competencies as the foundation of knowledge and skills need by everyone; these can be developed through training and are relatively easy to identify. From the statement, the researcher might conclude that the competencies of an individual might be developed through training programs. Tjutju Yuniarsih $(2008)^{8}$ states that 
the knowledge competencies and the skill competencies are relatively easy to develop and the learning and training programs are the most effective ways for developing these competencies. Therefore, learning programs, training programs and the combination of both programs in the working place will be the main key for developing and improving the competencies.

The Engineering Elements Course is a course that will be the foundation of engineering shaft planning. Therefore, the explanation of engineering shaft will be better if it is assisted by the object. Based on the learning experiences, the researcher found that many university students have not understood that object that will be planned. The same findings might also be seen in the results of a test conducted in 2015: only $20 \%$ of the students had been able to achieve the limit of the already formulated competencies. Since the competencies have not been achieved in accordance to the expectation, the lecturers should benefit the existing engineering laboratory as the learning media for Engineering Elements Course especially in the shaft planning.

Based on the explanation, the engineering laboratory might be used as the learning medium in order to improve the university students' learning results in the Engineering Element Course especially in the shaft planning. In addition, the engineering laboratory might also be used for increasing the size of influence so that the lecturers might improve the competencies on the learning results.

\section{Research Methods:-}

The study made use of quasi-experiment approach by taking all of the Engineering Education Study Program students who took the Engineering Elements Course in 2015 as the respondents and the number of the respondents were 49 people. The study took place in the Department of Engineering Semarang State University and the study was conducted in the classroom and in the laboratory. The classroom session was related to learning the theory all aspects that had been related to the shaft planing. Then, the laboratory session was related to learning all types of shafts, the forces that worked on the shaft, the materials that should be used and the allowed positioning and tolerance. All tests were conducted after the session had ended.

In order to gain the accurate data regarding the unclear problems for the students, there should be several personal approaches and these approaches might be conducted by increasing the number of consultation sessions for the students whose test results had been less than the already determined criteria (under 75). All of the data from the test results were analyzed by means of Partial Least Square (PLS) program in order to measure the improvement on the test results and several factors that influenced the improvement.

\section{Results And Discussion:-}

\section{Competence Improvement on the Test Results:}

Test Results:

The test results were the reflection of the competence achievement that had been attained from the test on each learning stage. In each learning stage, there were three components that had been assessed namely knowledge (A), analysis (B) and calculation results (C). The final score consisted of $\mathrm{A}+\mathrm{B}+\mathrm{C}$ and the results of summation would be divided by three; the final score will be the final result for each learning process. The conclusion of the test results in the Learning Stage I might be seen in the following Table 1:

Table 1:- Learning Stage I (P1) Test Results.

\begin{tabular}{|l|r|r|r|r|}
\hline Score & A1 & B1 & C1 & P1 \\
\hline Mean & 83 & 56 & 37 & 59 \\
\hline Total & 4075 & 2775 & 1835 & 2915 \\
\hline Min & 80 & 30 & 25 & 45 \\
\hline Max & 90 & 80 & 55 & 75 \\
\hline
\end{tabular}

From Table 1, the researcher might state as well that from the Learning Stage I results (P1) the mean score was 59 and the total score was 2916 with 45 as the lowest score and 75 as the highest score. From the test results in the first stage there were only 5 students (10\%) who had been able to achieve the minimum passing grade that had been determined. The achievement above the minimum passing grade was heavily supported by the A1 score, which referred to the score of knowledge.

Learning Stage II (P2) Test Results. 
Table 2:- Learning Stage II (P2) Test Results.

\begin{tabular}{|l|r|r|r|r|}
\hline Score & A2 & B2 & C2 & P2 \\
\hline Mean & 86 & 76 & 59 & 74 \\
\hline Total & 4245 & 3755 & 2905 & 3625 \\
\hline Min & 80 & 70 & 40 & 65 \\
\hline Max & 90 & 85 & 70 & 80 \\
\hline
\end{tabular}

The conclusion of the Learning Stage II results might be seen in the following Table 2 .

From Table 2, the researcher might conclude that from the Learning Stage II (P2) results the mean score was 74 and the total score was 3625 with 65 as the lowest score and 90 as the highest score. From the second test, there were 20 students $(40 \%)$ who had been able to achieve the minimum passing grade that had been determined. Learning Stage III (P3) Test Results.

Table 3:- Learning Stage III (P3) Test Results.

\begin{tabular}{|l|r|r|r|r|}
\hline Score & A3 & B3 & C3 & P3 \\
\hline Mean & 86 & 84 & 83 & 85 \\
\hline Total & 4235 & 4130 & 4105 & 4155 \\
\hline Min & 80 & 80 & 80 & 80 \\
\hline Max & 95 & 95 & 95 & 95 \\
\hline
\end{tabular}

The conclusion on the Learning Stage III (P3) test results might be seen in the following Table 3.

From Table 3, the researcher might conclude that from the Learning Stage III (P3) test results the mean score was 84 and the total score was 4155 with 80 as the lowest score and 95 as the highest score. From the third test all of the students $(49=100 \%)$ might achieve the minimum passing grade that had been determined.

Improvement on the Competence Test Results

There were three aspects that might be measured in terms of test result improvement namely knowledge (A), analysis (B) and calculation result (C). The improvement on the competence test result was attained twice, namely the improvement on the Second Learning Stage (P2) test results from the First Stage Learning Stage (P1) test results and the improvement on the Third Learning Stage (P3) test results from the Second Learning Stage (P2) test results. Improvement on the Learning Stage I (P1) Competence Test Results and the Learning Stage II (P2) Competence Test Results on the Aspect of Knowledge (A1 and A2).

Table 4:- Improvement on the A1 Knowledge Test Results and A2 Knowledge Test Results.

\begin{tabular}{|c|c|c|c|c|}
\hline Test & $\mathrm{N}$ & Mean & Standard Deviation & - T Statistics \\
\hline A1 & 49 & 83 & 3.636 & $1.101-$ \\
\hline A2 & 49 & 86 & 3.444 & - \\
\hline
\end{tabular}

In Table 4, the researcher found that the mean score of A1 knowledge test was 83 and the mean score of A2 knowledge test was 86 . The T-Statistics $=1.101$ and this score was smaller than T-table $=1.69$. These findings show that there had been improvement on the knowledge test results but the improvement was not significant and the improvement had been marked by the increasing test results in A2 from A1 and by the T-count that had been smaller than the T-table. The improvement in overall was $3.5 \%$.

Improvement on the Learning Stage II (P2) Competence Test Results and the Learning Stage III (P3) Competence Test Results in the Aspect of Knowledge (A2 and A3).

Table 5:- Improvement on the A2 Knowledge Test Results and A3 Knowledge Test Results.

\begin{tabular}{|c|c|c|c|c|}
\hline Test & $\mathrm{N}$ & Mean & Standard Deviation & T Statistics \\
\hline A2 & 49 & 86 & 3.444 & 0.76 \\
\hline A3 & 49 & 87 & 5.103 & - \\
\hline
\end{tabular}

In Table 5, the researcher found that the mean score of A2 knowledge test was 86 and the mean score of A3 knowledge test was 87. The T-Statistics $=0.76$ and the score was smaller than T-table $=1.69$. Thereby, the researcher might conclude that there had been improvement on the knowledge test results but the improvement was not significant and the improvement had been marked by the increasing test results in A3 from A2 and by the TCount that had been smaller than the T-table. The improvement in overall was $1.1 \%$. 
The Improvement on the Learning Stage I (P1) Competence Test Results and the Learning Stage II (P2) Competence Test Results in the Aspect of Analysis (B1 and B2).

Table 6:- Improvement on the B1 Analysis Test Results and B2 Analysis Test Results.

\begin{tabular}{|l|l|r|r|r|}
\hline Test & N & \multicolumn{1}{|c|}{ Mean } & Standard Deviation & \multicolumn{1}{c|}{ - T Statistics } \\
\hline B1 & 49 & 56 & 15.730 & 12.34 \\
\hline B2 & 49 & 76 & 4.256 & - \\
\hline
\end{tabular}

In Table 6, the researcher found that the mean score of B1 analysis test results was 56 and the mean score of B2 analysis test results was 76. The T-Table $=12.34$ and the score was bigger than T-table $=1.69$. These findings showed that there had been significant improvement on analysis test results and the improvement had been marked by the increasing mean score of test results in B2 from B1 and by the T-count that had been bigger than the T-table. The improvement in overall was $40 \%$.

Improvement on the Learning Stage III (P3) Competence Test Results from the Learning Stage II (P2) Competence Test Results on the Aspect of Analysis (B3 from B2).

Table 7:- Improvement on the B3 Analysis Test Results from the B2 Analysis Test Results.

\begin{tabular}{|l|l|l|l|l|}
\hline Test & N & Mean & Standard Deviation & - T Statistics \\
\hline B2 & 49 & 76 & 4.256 & 9.63 \\
\hline B3 & 49 & 84 & 4.208 & - \\
\hline
\end{tabular}

In Table 7, the researcher found that the mean score of B2 analysis test results was 76 and the mean score of B3 analysis test results was 84 . The T-Statistics $=9.63$ and the score had been bigger than the T-table $=1.69$. Thereby, the researcher might conclude that there had been significant improvement on the test results and the improvement had been marked by the increasing B 3 test results from B 2 test results and by the T-count that had been bigger than the T-table. In overall the improvement was $10.5 \%$.

Improvement on the Learning Stage II (P2) Competence Test Results from the Learning Stage I (P1) Competence Test Results in the Aspect of Calculation Results (C2 from C1).

Table 8:- Improvement on the Test Results of C2 Calculation Result from C1 Calculation Result.

\begin{tabular}{|l|l|r|r|rr|}
\hline Test & N & \multicolumn{2}{|c|}{ Mean } & Standard Deviation & - T Statistics \\
\hline C1 & 49 & 37 & 8.173 & 12.30 \\
\hline C2 & 49 & 59 & 9.895 & - \\
\hline
\end{tabular}

In Table 8, the researcher found thato the mean score of $\mathrm{C} 1$ was 37 and the mean score of $\mathrm{C} 2$ was 59. The TStatistics $=12.30$ and the score was bigger than the T-table $=1.69$. These findings showed that there had been significant improvement and the significant improvement had been marked the increasing test results of $\mathrm{C} 2$ from those of $\mathrm{C} 1$ and by the T-count that had been bigger than the T-table. In overall the improvement was $59.4 \%$.

Improvement on the Learning Stage III (P3) Competence Test Results and the Learning Stage II (P2) Competence Test Results on the Aspect of Calculation Results (C3 from C2).

Table 9:- Improvement on the Test Results of C3 Calculation Result from C2 Calculation Result.

\begin{tabular}{|l|l|r|r|r|}
\hline Test & N & \multicolumn{1}{|c|}{ Mean } & Standard Deviation & \multicolumn{2}{c|}{ - T Statistics } \\
\hline C2 & 49 & 59 & 9.895 & 21.33 \\
\hline C3 & 49 & 83 & 4.273 & - \\
\hline
\end{tabular}

In Table 9, the researcher found that the mean score of $\mathrm{C} 2$ as 59 and the mean score of $\mathrm{C} 3$ was 83 . The $\mathrm{T}$-Statistics $=$ 21.33 and the score had been bigger than the T-table $=1.69$. Thereby, the researcher might conclude that there had been significant improvement and the significant improvement had been marked by the increasing test results of C3 from C2 and the T-table that had been bigger than the T-count. In overall, the improvement was $46.1 \%$.

Improvement on the Learning Stage II (P2) Cummulative Competence Test Results from the Learning Stage I (P1) Cummulative Competence Test Results.

The results of Learning Stage (P) competence test was a score that had been consisted of knowledge (A) score plus analysis $(\mathrm{B})$ score plus calculation result $(\mathrm{C})$ divided by $3(\mathrm{P}=\mathrm{A}+\mathrm{B}+\mathrm{C}) / 3))$. 
Table 10:- Improvement from the Learning Stage II (P2) Competence Test Results from the Learning Stage I (P1) Competence Test Results.

\begin{tabular}{|l|l|r|r|r|}
\hline Test & N & Mean & Standard Deviation & \multicolumn{2}{|c|}{ - T Statistics } \\
\hline P1 & 49 & 59 & 9.199 & 7.15 \\
\hline P2 & 49 & 74 & 4.998 & - \\
\hline
\end{tabular}

In Table 10, the researcher found that the mean score of P1 test results was 59 and the mean score of P2 test results was 74 . The T-Statistics $=7.15$ and the score had been bigger than the T-table $[=1.69$. These findings showed that there had been improvement on the learning stage cummlative test results and the improvement had been marked by the increasing mean score in P2 from P1 and by the T-count that had been bigger than the T-table. In overall, the improvement was $25.6 \%$.

Improvement on the Learning Stage III (P3) Cummulative Competence Test Results from the Learning Stage II (P2) Cummulative Competence Test Results.

Table 11:- Improvement on the Learning Stage III (P3) Cummulative Competence Test Results and the Learning Stage II (P2) Cummulative Competence Test Results.

\begin{tabular}{|l|l|l|l|r|}
\hline Test & N & Mean & Standard Deviation & - T Statistics \\
\hline P2 & 49 & 74 & 7.211 & 4.331 \\
\hline P3 & 49 & 85 & 1.523 & - \\
\hline
\end{tabular}

In Table 11, the researcher found that the mean score of P3 competence test results was 74 and the mean score of P2 competence test results was 85 . The T-Statistics $=4.331$ and the score had been bigger T-table $=1.69$. These findings showed that there had been significant improvement on the cummulative competence test results and the significant improvement had been marked by the increasing mean score of $\mathrm{P} 2$ from $\mathrm{P} 2$ and the T-count that had been bigger than the T-table. In overall, the improvement was $14.89 \%$.

\section{Discussions:-}

The learning activity that the researcher conducted was direct observation toward the object that would be planned. By directly observing the object that would be planned, the students had better comprehension and increasing competence. This finding was in accordance with the statement of Azhar $(2003)^{3}$ that the main level of learning mode had been the direct experience (enactive level). Learning by means of vision would cause the students to retrieve more learning materials. Furthermore, Saiful Sagala $(2002)^{6}$ stated that the attainment of learning results through the vision of an individual might approximately be $75 \%$. Thereby, the results of the study had proved the studies conducted by the experts.

Two most important elements in the learning process were the teaching methods and the learning media. Both aspects were related from one to another and the selection of certain teaching methods would influence the appropriate learning media. In the learning activities that had been conducted, the students were invited to the engineering laboratory in order to observe the object that would be planned. The students apparently were very interested with what they saw in the engineering laboratory, namely the engine shaft; then, they asked the functions of the engine shaft and how to plan and to design the shaft. From the situation, the researcher might infer that the teaching methods and the learning media that had been implemented might draw the interest, might provide better information and might send very beneficial learning messages. The statement was in accordance with the statement of Jujun $(2003)^{5}$ that good learning media should be able to meet the main three functions namely to motivate interest or action, to provide information and to give instruction. The teaching method that had been selected was also in accordance with the statement of Saiful Sagala $(2001)^{6}$ who stated that the benefits of learning media in the teaching-learning process were: the learning media would draw more attention, the teaching matterials would provide better meaning, the teaching methods would be more various and the students might display greater learning desires. From the results of the study regarding the engineering laboratory-based learning process the researcher found many situations that had been in accordance with those of other studies and, therefore, the researcher might conclude that the practical benefit of using learning media had been to ease and to improve the learning process and results. From the perspective of learning theory, multiple conditions and psychological principles that should be considered in selecting and in using the learning media were the ones that would increase the students' motivation. 
The competence improvement on the university students' learning results in the study was also in accordance with the results of a study by Eka Ariyani (2009) ${ }^{9}$, which concluded that the learning of ecosystem and biodiversity through the laboratory practice-based learning process might significantly improve the critical thinking capacity of the university students with the moderate category. Furthermore, the results of a study by Ketut Suma (2009) ${ }^{9}$ also stated that the inquiry-based learning had been more effective in increasing the content of Physics and the reasoning capacity of teacher-candidate students in the moderate level.

In overall, the results of the study showed that there had been competence improvement in the learning results of the university students after the students directly observed the object that would be planned. The competence improvement was proved by the improvement on the mean score of the test that had been conducted.

The results of the study were also in accordance with those of a study by R. Mursid (2013) ${ }^{9}$, which concluded that the development of product-oriented competence-based practical learning model might improve the learning results of university students in the Engineering Technology Course. Then, the results of the study were also supported by those of a study by M. Wahyudi (2014) ${ }^{9}$, which stated that the demonstration learning might improve the results of engine regular service practice for the vocational high school teachers in the automotive engineering departments under the training and education program of vocational competence in P4TK BOE Malang. The researcher found that the practical course should be supported by the appropriate use of learning media in order to improve the competence of learning results. Rabiman $(2014)^{9}$ stated that the selection of appropriate learning media might improve the learning results of university students in the Department of Engineering, Sarjanawiyata Tamansiswa University, Yogyakarta. The improvement on the competence of test results was not apart of the implementation of the modul that had been appropriate to the context that would be studied. As having been stated by Wijanarka et al. $(2014)^{9}$, the results of implementing the CAD/CAM software modules might improvement the theoretical competencies and the practical competencies of the vocational high school students in Yogyakarta. In overall, the results of the study also stated that the overall learning process that had been conducted should be supported by innovation in order to improve the competence of the learning results.

Based on the overall results of the study regarding the use of laboratory for providing clear information in the learning process, the researcher found that the overall learning process might improve the competence of the students' learning results. It was the overall learning process that had been suitable to the results of the study that had been conducted, namely the overall learning process that made use of the tools and the objects in the laboratory so that the learning process would be more interesting and would provide better materials that would be taught in the learning process.

\section{Limitations:-}

In conducting the study, the researcher encountered several limitations namely the abundant number of university students, the laboratory that had not been designed, the laboratory room that had not been sufficient and the tools and objects that had not been sufficient. The university students were too many to serve as the respondents so that they exceeded the capacity that had been in accordance with the learning standard (20 students). Then, the laboratory had not been designed in accordance with the standards of engineering tools and objects placement and operation. Next, the laboratory room had not been sufficient in terms of placement and operation. Last but not the least, the engineering tools and objects had not been sufficient as well in terms of amount and quality standard. In conducting the study, the researcher provided opportunity for the university students to ask all matters that they had not understood. Thereby, the university students might attain more detailed explanation from the lecturer and the data gathering activity might be conducted correctly and appropriately.

\section{Strengths:-}

The learning plan and the learning test might cause the learning development of the university students to be more directed and the researcher might immediately find the weaknesses on the students' consideration in planning and in calculating the engineering elements. In addition, the researcher might also identify the improvement in each step of university students' considerations and these considerations would be evaluated by the researcher in order to define the appropriate solution. From the statements, it was apparent that all of the competence elements that the university students had, both the ones in the form of knowledge and of analysis, might be evaluated in depth and in details. Thereby, the university students' strengths and weaknesses in the thinking process might be identified immediately. 


\section{Conclusion:-}

From the results of the study, the researcher would like to conclude that there are three aspects that might be measured in identifying the improvement on the competence results, namely knowledge score (A), analysis score (B) and calculation result score (C) altogether with the learning results score. The improvement on the A1 and the A2 knowledge competence test results has been $3.5 \%$ and has not been significant. The improvement on the A2 and the A3 knowledge competence test results has been $1.1 \%$ and has not been significant as well. Then, the improvement on the B1 and the B2 analysis competence test results has been $40 \%$ and has been significant. The improvement on the $\mathrm{B} 2$ and the $\mathrm{B} 3$ analysis competence test results has been $10.5 \%$ and has been significant as well. Next, the improvement on the $\mathrm{C} 1$ and the $\mathrm{C} 2$ calculation result competence test results has been $59.4 \%$ and has been significant. The improvement on the $\mathrm{C} 2$ and the $\mathrm{C} 3$ calculation result competence test results has been $46.1 \%$ and has been significant as well. Altogether, the improvement on the P1 and the P2 learning competence test results has been $25 \%$ and has been significant. The improvement on the P2 and the P3 learning competence test results has been $14.84 \%$ and has been significant as well.

Based on the study that has been conducted, the researcher would like to suggest that all of the analytical and calculation-involving engineering courses should make use of real objects in order to provide better explanation for the university students.

\section{References:-}

1. Arief Sadiman. 2002. Media Pendidikan Pengertian, Pengembangan dan Pemanfaatannya. Cetakan Kelima. Jakarta: Penerbit PT Raja Grafindo Persada.

2. Ali, Imron. 2002. Pembinaan Guru di Indonesia, Cetakan Pertama, Malang: Penerbit Pustaka Jaya.

3. Azhar, Arsyad. 2003. Media Pembelajaran, Cetakan ketiga. Jakarta: Penerbit PT Raja Grafindo Persada.

4. Skinner, B.F.(1998). The Technology of teaching. New York: AppletonCentury Crofts.

5. Jujun S, Suriasumantri. 2003. Filsafat Ilmu Sebuah Pengantar Filsafat. Jakarta: Penerbit Pustaka Sinar Harapan.

6. Syaiful Sagala. 2003. Konsep dan Makna Pembelajaran. Bandung: Penerbit Alfabeta.

7. Spencer, L.M.dan Spencer, S.M. (1993). Competence at work. Boston: Gorham \& Lambert.

8. Tjutju Yuniarsih \& Suwatno. (2008). Manajemen sumber daya manusia. Bandung: Alfabeta.

9. Susan Gunelius. (2015) A blog is a website consisting of entries. Download 15 agustus 2015: http://weblogs.about.com/od/startingablog/p/WhatIsABlog.htm

10. Murdani \& Hadromi. 2015. Meningkatkan Kompetensi Hasil Belajar Mahasiswa pada Pokok Bahasan Perencanaan Bagian Pemesinan dengan Memanfaatkan Media Alat Mesin yang Ada di Laboratorium Teknik Mesin. Semarang: laporan hasil penelitian. Tidak diterbitkan. 